\title{
Implementation of Mataram City Regulation Number 5 Year 2019 Concerning Mataram City Spatial Plan, 2011-2031 on Fishermen House Relocation Plan in the Coastal Area of Mataram City
}

\author{
Adyanta Pangestu Galang Asmara Arba \\ Postgraduate Program, University of Mataram, Indonesia
}

\begin{abstract}
The purpose of this study is to analyze the implementation of the relocation of fishermen's houses and the fulfillment of the rights of people in the coastal area of Mataram City based on Mataram City Regulation No. 5 of 2019 concerning Spatial Plan of Mataram City In 2011-2031. This research uses normative and empirical legal research using statutory, conceptual and sociological approach methods. The type and source of legal materials is done through literature and field data. Analysis of legal materials using qualitative normative analysis methods. Based on the results of the study, it is known that the implementation of relocation is not fully realized due to the lack of socialization conducted by the government to coastal residents, the rights of the affected communities are done by providing compensation to people who have proof of the right to land that they previously occupied.
\end{abstract}

Keywords: Regional Regulation,. Relocation, Fishing Society

DOI: $10.7176 / \mathrm{JLPG} / 112-04$

Publication date:August $31^{\text {st }} 2021$

\section{INTRODUCTION}

The planning pattern of the city area is more oriented towards the activities of community service center development, opening up direct employment access for the community considering the concentration of the population tends to be in urban areas. Therefore, the orientation of the pattern of use of the city area is in accordance with its objectives, namely to realize the city area as the center of government, education, trade and services, industry and tourism based on local wisdom supported by balanced urban facilities and infrastructure and environmentally sound based on the vision and mission of the city government. (Arba, 2017)

Regional authority in maintaining the spatial arrangement of the region philosophically set in the consideration UUTR namely to strengthen national resilience based on the insight of the archipelago and in line with the policy of regional autonomy that gives greater authority to the local government in the implementation of spatial arrangement, then the authority needs to be regulated in order to maintain harmony and cohesion between regions and between the center and the region so as not to cause gaps between regions. So that Article 11 paragraph (1) UUTR expressly gives attribution authority, namely the authority of the district / city government in the implementation of spatial arrangements include:

a. regulation, development, and supervision of the implementation of spatial arrangements of districts / cities and strategic areas of districts / cities;

b. implementation of spatial arrangement of districts / cities;

c. implementation of spatial arrangement of strategic areas of districts / cities; and

d. cooperation of spatial arrangement between districts / cities.

Mataram City Government Policy in regulating spatial planning of Mataram City coastal area is stated in Article 11 paragraph (2) of Regulation No. 5 of 2019 concerning Spatial Plan of Mataram City In 2011-2031, that the strategy of housing area development is as follows:

a. improving the quality of residential areas;

b. organizing densely populated and/or slum areas in the City area;

c. developing infrastructure and facilities for settlements;

d. limiting the development of linear settlement patterns by directing the development of vertically dense settlement patterns;

e. avoid the development of settlements in RTH (Green open space) located in the border area and outside the city center;

f. provide green open space in accordance with spatial planning principles in residential areas and optimize its function;

g. to relocate and / or rearrange fishing villages in areas prone to the threat of tidal waves / tsunamis and coastal abrasion;

h. reorganize housing along river banks and coastal borders.

In the relocation of the residential area of coastal fishermen's houses. The government must provide 
commensurate compensation even if it is in the public interest. Because the taking of people's land by anyone, including by the government, should not be done arbitrarily, even for any reason, including reasons for the public interest.(Limbong, 2017) If forced, people's land is taken for development for the public interest, then the development must be based on law and by providing appropriate compensation in accordance with Law no. 2 of 2012 concerning Land Acquisition for Development in Public Interest, must compensate according to the calculation in the law.

Regional Regulation Number 5 of 2019 concerning the Regional Spatial Plan for the City of Mataram for 2011-2031, has so far not been consistent and coherent with the spirit of the Constitution and the spatial planning law, due to ineffective management of the legal structure (Mataram City Government). In fact, the relocation of fishermen's houses in coastal areas must be managed properly because it will be bad for the environment and society, as according to Gatot that spatial law is a law related to spatial wisdom, directed to the achievement or preservation of the best reciprocal adjustment between space and people's lives.

From the description above, it is necessary to carry out research related to the implementation of Mataram City Regional Regulation Number 5 of 2019 concerning the Regional Spatial Plan for the City of Mataram in 2011-2031 of the Planned Relocation of Fishermen's Houses in the Coastal Areas of Mataram City..

\section{Formulation of the problem}

1. How to implement the relocation of fishermen's houses in the coastal area of Mataram City based on Mataram City Regulation No. 5 of 2019 concerning Spatial Plan of Mataram City In 2011-2031?

2. How to fulfill the rights of the affected communities in the implementation of the relocation of fishing houses in the coastal area of Mataram City?

\section{Theoretical basis}

\section{a. Theory of Justice}

Justice is the main virtue in social institutions, as truth in the system of thought. A theory, however elegant and economical, should be rejected or revised if it is not true. So are laws and institutions, no matter how. Efficient and tidy must be reformed or abolished if it is unfair.(John, 2006) Justice does not allow the sacrifices imposed on a handful of people to be toughened by as the great justness of the freedom of citizens is considered well established. The rights guaranteed by justice are not subject to political bargaining or calculation of social interests.(John, 2006)

Hans Kelsen thinks that the law as a social order that can be declared fair if it can regulate human actions in a satisfactory way so as to find happiness in it.(Hans, 2011) According to Sajipto, legal positivism itself turns out to be unable to follow the sense of justice that grows in society because written laws cannot be changed at any time. The sense of justice that is reflected in a kibab of a law, for example, may only be in tune with the sense of justice in society at the time the law is written. A society that is constantly changing brings about changes in the justice that lives in society. because perceived existing provisions no longer reflect another sense of justice, and this means people hold back to the teachings of the laws of nature. Often people call the rise of the doctrine of the law of nature.(Rasjidi, 2012)

\section{b. Usability Theory}

The purpose of law can be seen in its function as a function of protecting human interests, law has goals to be achieved.(Said, 2011). Regarding the benefit of this law according to the utilization theory, it wants to guarantee the happiness that is impressed by humans in as many numbers as possible. In essence, according to this theory, the purpose of law is the benefit in producing the greatest pleasure or happiness for a large number of people.

According to Utrecht, the law guarantees legal certainty in human relations. Utrecht's assumption is based on the assumption that the law to safeguard the interests of every human being so that the interests can not be disturbed (containing consideration of which interests are greater than others).(Ridwansyah, 2016)

In the framework of utilitarianism (utilitarianism) the criteria for determining whether an action is good or bad is "the greatest happiness of the great est number", the greatest happiness of the largest number of people. The deeds that have caused most people to feel happy and satisfied are the best deeds. Utilitarianism as a basic concept of ethics is realized in the fundamentals of economic thought.

According to Weiss, there are 3 (three) basic concepts regarding utilitarianism as follows:(Ridwansyah, 2016)

1. An action or deed or decision which is morally correct if that action or deed or decision making makes the best for many people who are influenced by the action or deed or decision making

2. An action or deed or decision that is morally correct if there is the best benefit for the costs incurred, compared to the benefits of all the possible options being considered.

3. An action or deed or decision making that is morally correct if the action or action or decision making is appropriately able to benefit, either directly or indirectly, for the future of each person. 


\section{c. Human Rights Theory}

As mentioned above, that the protection of human rights is one of the main elements of the state of law both based on the concept of Rechtsstaat, The Rule of Law, and the State law of Pancasila. Other elements such as the principle of legality, the division of state power, a free and impartial judiciary, democracy is a further consequence of the purpose of the state law to protect and guarantee the human rights of its citizens from acts of arbitrariness.(Rasjidi, 2012)

The concept of human rights in the 1945 Constitution (UUD 1945) is different from the individualistic Western concept. In individualistic societies, there is a tendency for excessive prosecution of human rights implementation. Whereas the implementation of human rights admonition absolutely means violating the human rights of others. The 1945 Constitution places humans as an individual being as well as a social being. Humans, it just means after interacted with other humans. In interaction with others must be balanced between rights and obligations on the basis of a just and civilized humanity.(Rasjidi, 2012)

\section{d. Law Enforcement Theory}

Law enforcement according to Barda Nawawi Arief is a whole series of activities to organize / maintain the balance of rights and obligations of citizens in accordance with human dignity and responsibility according to their functions fairly and equitably, with legal rules and legal regulations and legislation which are the manifestation of Pancasila and The 1945 Constitution and Law Enforcement are also the overall activities of law enforcers towards the enforcement of law, justice and protection of human dignity, order, peace and legal certainty in accordance with the 1945 Constitution..(Arief, 2000)

Conceptually, the meaning of law enforcement lies in the activity of conveying the relationship of values that are described in solid and embodied principles and attitudes as a series of final stage value descriptions, to create, maintain, and maintain a peaceful social life.(Soekanto, 2007). In enforcing the law, there are three elements that must be considered, namely legal certainty, benefit and justice.

In law enforcement that can fulfill a sense of legal justice, there are many factors that influence it. These factors are of importance from the implementation to the stage of the court's decision. These factors include legal or statutory factors, law enforcement factors, supporting facilities and infrastructure, community factors.

\section{a. The Concept of Authority and Duties of Regional Government}

Regarding sources of authority, it can be obtained through three sources, namely attribution, mandate, and retribution, which is contained in Article 11 then the definition of the 3 sources of authority is in Article 1 numbers 22, 23, and 24 of Law Number 30 of 2014 concerning Government Administration which explains source of authority.

The Regional Government Law consistently displays an expression of centralism in government administration when formulating provisions regarding the transfer of authority (decentralization).(Dapu, 2016) In other words, decentralization and autonomy are two sides of one coin (both sides of one coin).(Sirajuddin \& Winardi, 2017) One of the objectives of the central government is to give confidence to the local government so that it is efficient and effective in line with the principles of good governance (Good Govermence) in order to accelerate the realization of public welfare and strengthen the integrity of the Unitary State of the Republic of Indonesia (NKRI).(Cornelis, 2016) In Law Number 23 of 2014 concerning Regional Government, broad autonomy means giving authority to regions to carry out only certain areas of government, namely concurrent government affairs which are regulated clearly and in detail in Law Number 23 of 2014 and are guided by Norms, Standards, Procedures and criteria set by the Central Government.(Simarmata, 2018)

\section{b. Spatial Concept}

Spatial planning, with an emphasis on "tata (governance)" is the arrangement of the spatial arrangement of a region (region) so as to create requirements that are economically, socio-culturally and politically beneficial, as well as beneficial for the development of the people of the region.(Wahid \& SH, 2016) While according to Juniarso Ridwan and Achmad Sodik which means space as one of the places to carry out human life, also as a natural resource is one of god's gifts to the Indonesian nation.(Ridwan et al., 2008)

The term spatial is an objective reality. Structural forms and patterns of space utilization can be orderly and harmonious, can also be chaotic.(Kuswartojo, 1999) While spatial law can provide limitations as the whole rule regulates the ins and outs in spatial arrangement, both heternom and autonomous.(Rijadi, 2005)

The basic principle of spatial planning adhered to by Law Number 26 of 2007 concerning Spatial Planning according to Ateng Syafrudin is the principle of integration in the use of space in an orderly, harmonious, balanced manner so that spatial planning efforts guarantee the preservation of environmental carrying capacity and support sustainable development to improve the welfare of future generations. present and future.(Wibowo, 2014)

\section{c. Regional Spatial Plan Concept (RTRW)}

Spatial planning and spatial use control will take place effectively and efficiently if it has been preceded by a valid and quality spatial planning. Regional Regulation (PERDA) of Mataram City Number 5 of 2019 concerning Amendments to Regional Regulation Number 12 of 2011 concerning Mataram City Regional Spatial 
Planning 2011-2031, that what is meant by Spatial Planning is the result of spatial planning, and Spatial Planning is a process for determining the spatial structure and spatial pattern which includes the preparation and determination of spatial plans. Meanwhile, the explanation for the word Wilayah is derived from Government Regulation Number 15 of 2010 concerning Spatial Planning, that a Region is a space which is a geographical unit along with all related elements whose boundaries and systems are determined based on administrative and / or functional aspects.

According to the Regulation of the Minister of Public Works Number 17 / PRT / M / 2009 concerning Guidelines for the Compilation of City Spatial Plans. City spatial planning (RTRW) is a spatial plan that is general in nature of the city area which is an elaboration of the provincial RTRW, and contains objectives, policies, urban spatial planning strategies, urban spatial structure plans, urban spatial pattern plans determination of the strategic city area, directions for the use of urban space, and provisions on controlling the use of city space.(Mokodongan et al., 2019)

\section{d. Relocation Concept}

Relocation comes from the English language consisting of 2 (two) words, namely "re" which means return and the "locati" of the place. Relocation or resettlement is the process of moving residents from housing locations that are not in accordance with their designation to a new location prepared in accordance with the city development plan.(Ridlo, 2001)

Relocation or Resettlement is the process of moving residents from a residential location to a new residential location that has been determined by the government and in accordance with housing development. In addition, resettlement is defined as the Process of compensation caused by natural disasters, evictions.

e. Coastal Area Concept

In Article 1 number (2) of Law Number 27 of 2007 concerning Management of Coastal Areas and Small Islands. The term Coastal area is a transitional area between land and sea Ecosystems which are affected by changes in land and sea. Furthermore, in number (8) what is meant by area is the part of the Coastal Zone and Small Islands which has a certain function which is determined based on the criteria of physical, biological, social and economic characteristics to maintain its existence.

\section{f. Concept of Housing and Residential Areas}

Housing is a form of housing that has a very close relationship with the community. This means that housing in a location reflects more or less the characteristics of the people who live in that housing.(Tugault, 1965)

Housing can be interpreted as a reflection of the human person, both individually and in unity and togetherness with the natural environment and can also reflect the standard of living, welfare, personality, and human civilization of its inhabitants, society or a nation.(Yudohusodo, 1991)

\section{Research Methods}

\section{Types of Legal Research}

The types of research used in this legal research are normative and empirical. Normative research is also called doctrinal legal research.

\section{Research Approach}

The approach used in this research:

1. Statute Approach, which is about the mechanism of the implementation of the relocation of fishing houses along the coast of Bintaro Village based on Mataram City Regulation No. 5 of 2019 concerning Spatial Plan of Mataram City In 2011-2031, and the obstacles faced in the implementation of the relocation of fishermen's houses in Bintaro Village.

2. Conceptual Approach, which is an approach that consists of the opinions of experts, the opinions of scholars and the opinions of legal experts.

3. Sociological approach, which is intended as an effort to approach the problem examined with a real legal nature or in accordance with the reality that lives in society.

\section{Sources And Types of Legal Materials and Data}

1) Literature Materials

a) Primary legal materials are binding legal materials related to this research, namely:

b) This secondary legal material consists of books, papers, articles and opinions expressed by experts or scholars who have an interest in the subject of research.

c) Tertiary Legal Materials, are materials that provide guidance and explanation of primary and secondary legal materials, such as legal dictionaries, encyclopedias, internet articles, and Indonesian dictionaries..

2) Field Data

a) Primary data. In this study, data were obtained from the Municipal Government of Mataram, the Regional Development Planning Agency (BAPPEDA) of Mataram City as respondents and the people of Bintaro Village who would be relocated as informants..

b) Secondary data, namely data in the form of official documents at the research location. 
Legal Materials and Data Collection Techniques.

1. Primary data is by conducting direct interviews, namely by preparing questions as a guide in advance but it is still possible with the situation during the interview.

2. Secondary data is data collected using document study techniques by collecting and studying sources such as literature, books, scientific articles, research results and laws and regulations relating to the subject matter.

Analysis of Legal Materials and Data.

The data obtained through this study were processed and analyzed using qualitative normative analysis methods. Normative analysis, namely research that has a starting point of existing regulations as positive legal norms, then data from the results of field research are inventoried and compiled systematically for further qualitative analysis.

\section{Results And Discussion}

Implementation of Relocation of Fishermen's Homes in the Coastal Areas of Mataram City Based on Mataram City Regional Regulation Number 5 of 2019 concerning Mataram City Spatial Planning for 2011-2031

Relocation is defined as the movement or relocation of location, either an industry or a trading place from one place to another for certain reasons.(Options, 1997) The meaning of relocation in the Indonesian dictionary is translated as rebuilding housing, assets, including productive land and public infrastructure in other locations or lands. So the relocation meant in this discussion is the act of transferring a place of residence from one physical location to another.

The policy to relocate community settlements in coastal areas is carried out as a permanent solution for residents who are often directly affected by sea water overflows / tidal waves to be moved to a safer settlement location. This relocation program is also intended to restore the function of the coastline as land for catchment areas.

In implementing the relocation of residents' settlements in coastal areas, the Mataram city government has coordinated both with the provincial and central government regarding planning up to the implementation stage. Based on the results of the compiler's interview with Mr. Wahyu Hidayat as the Head of the Public Works, Settlement and Transportation Sub-Division of the NTB Province Bappeda,

1. Selection of Relocation Area Location and quality of the place

New relocation is an important factor in relocation planning, because it greatly determines the ease of accessing to business land, social networks, jobs, business fields, credit and market opportunities. Each location has its own limitations and opportunities. Choosing a location that is similar to the previous area (the old place) in terms of environmental, social, cultural and economic characteristics will make it more likely that relocation and income recovery is successful. Ideally, the new relocation site should be geographically close to the old / original place to maintain social networks and good public relations. In urban development projects, which often result in relocation in large numbers, these impacts can be reduced by relocating to various small and close areas. In such cases, site selection and relocation plans must be based on, and decided upon by discussion liberation with the community.

2. Rights of the people to be transferred

To the community, information about prospective locations is conveyed and given the opportunity to review the sites that have been built before being officially handed over. This is necessary so that people can make choices freely.

Residents who have been informed of the relocation are given the opportunity to review the new location that will be used as their residence.

1. Physical completeness of the settlement location

The observations of the constituents in the field are known that the road access in the new settlement is quite feasible, it is because the location of the new settlement is on the cross-district route between Mataram City and West Lombok Regency, so access to reach the location of the new settlement is very easy to reach.. In addition to proper road access, the location of the new settlement should have a good drainage channel in the sense that in case of rain does not result in flooding in the residential area.

Provision of a new location must pay attention to the availability of clean water for the community / residents who are relocated, this is very important to pay attention to considering that water is a daily need for residents / communities to cook, bathe, wash, etc., besides that, the availability of clean water for residents will keep society away from diseases. Before moving a community to a new place, the city government must pay attention to the availability of electrical connections in the new settlement, so that when the building / settlement has been moved the community has not been connected by electricity.

Preparation of spatial planning needs to prioritize disaster events or whatever has happened or is about to 
occur. Many problems arose when compiling this plan, especially after the abrasion disaster in the coastal area of the Ampenan District due to changes in the morphology, topography, and socio-economic conditions of the community. In accordance with Law Number 26 of 2007 concerning Spatial Planning, districts and cities are given the authority to compile comprehensive spatial plans by utilizing space and supervising and controlling activities within the space.

The coastal area of Mataram City, which is administratively a part of Ampenan District, is an area that is often affected by coastal abrasion disasters marked by damage to most of the houses, socio-economic facilities, and road networks. In accordance with the development strategy of the city of Mataram, the regional spatial plan will develop a new, safer residential area.

The growth of development in the City of Mataram is progressing rapidly. Meanwhile, in terms of spatial function, most of the coastal areas do not allow for the physical development of the city, so that development tends to develop in a direction that is relatively safer from natural disasters and has the potential to become a new development. In order to accelerate the disaster management process and the resulting extraordinary impacts, the government issued Mataram City Regional Regulation Number 5 of 2019 concerning the Mataram City Spatial Plan 2011-2031. The regional spatial plan for the city of Mataram in the context of a strategy for developing housing areas, namely relocating coastal areas In Article 11 paragraph 2 letter g Mataram City Regional Regulation Number 5 of 2019 concerning Mataram City Regional Spatial Planning 2011-2031 which states :

"Relocating and / or rearranging fishing villages in areas prone to the threat of tidal waves / tsunamis and coastal abrasion".

Relocation and / or restructuring of fishing villages is carried out in several sub-districts in Ampenan District, in accordance with Article 34 letter e which states :

"Relocating and / or rearranging fishing settlements in Bintaro Village, Ampenan Tengah Village, Banjar Village and Ampenan Selatan Village, Ampenan District; Kelurahan Tanjung Karang Permai, Kelurahan Tanjung Karang and Kelurahan Jempong Baru, Kecamatan Sekarbela.”

Related to the implementation stage in Local Regulation No. 5 of 2019 concerning Spatial Plan of Mataram City In 2011-2031, it does not mention how the stages of implementation of coastal community relocation are carried out. In the regional regulation of Mataram City only mentions which areas will be relocated / reorganized and the purpose or purpose of relocation.

Spatial Plan of City Area which is hereinafter abbreviated as RTRW Kota is a plan to regulate the structure and pattern of spatial areas of the City which is the result of spatial planning activities. Space can be interpreted as a container of human life and other living things and as a natural resource. Space both as a container and as a limited natural resource. As a container, it is limited to the size of the area, while resources, it has limited carrying capacity, therefore according to space utilization it needs to be arranged so that there is no waste and a decrease in the quality of space. (Kantaatmadja, 1994)In Law No. 26 of 2007 concerning Spatial Planning (abbreviated as UUPR), space consists of regional and regional spaces. The definition of an area in Article 1 point 17 of the UUPR is a space which is a geographical unit along with all related elements whose boundaries and systems are determined based on administrative and / or functional aspects. Meanwhile, the definition of an area in Article 1 point 20 of the UUPR is an area which has the main function of protection or cultivation.

Article 1 Number 2 Law Number 26 of 2007 concerning Spatial Planning states that spatial planning is a form of spatial structure and spatial pattern, further Article 1 Number 3 states that spatial structure is the arrangement of settlement centers and a system of infrastructure and infrastructure networks that function as support for social activities. hierarchical societal economy has functional relationships.

Spatial planning means an organized arrangement of spaces. The word organized includes a harmonious and simple definition so that it is easy to understand and implement. Because in spatial planning, what is arranged is the place where various activities are carried out and the facilities and infrastructure are carried out. A good spatial layout can be implemented from all good structuring activities called spatial planning. In this case spatial planning consists of three main activities, namely spatial planning, spatial planning and spatial control.(Daud Silalahi, 2001)

Mataram City Regional Regulation Number 5 of 2019 concerning Mataram City Regional Spatial Planning 2011-2031 contains 12 Chapters with 107 Articles. This regional regulation regulates in general the principles, aims, objectives and spatial planning of the city of Mataram. This regional regulation was made with the consideration that in order to carry out the development of the Mataram City area in an integrated, sustainable, optimal, balanced and harmonious manner, according to its characteristics, functions and predicates, a basis is needed for planning guidelines, utilization and control of space in the area of Mataram City. This Regional Regulation states that " City Spatial Planning, hereinafter abbreviated as RTRW City is a plan to regulate the structure and pattern of city space which is the result of spatial planning activities."

The development of a regional spatial plan for the City of Mataram becomes a guideline for spatial use and control of spatial use in the arrangement / development of the City area. The spatial planning strategy for the 
City of Mataram includes: :

1. Planning

This planning includes structural planning and spatial use patterns carried out by considering harmony, harmony and balance of cultivation and protection functions, time dimensions, technology, socio-culture and defense and security functions by taking into account the integrated management aspects of various resources, functions and aesthetics of the environment as well as space quality. This planning is carried out in an integrated manner by involving all components in the region, including the government, community elements, universities and all existing stakeholders.

2. Utilization; includes functions, patterns and utilization of space in accordance with predetermined allotments.

3. Management; includes management of natural resources, human resources and financial resources in the form of costs and estimates in optimal and efficient and effective use of space.

Management regarding spatial planning for the coastal coastal area of Mataram City is contained in Article 34 Paragraph 2 Point e Perda Number 5 Year 2019 concerning Regional Spatial Planning for Mataram City 2011-2031.

Based on the results of the author's research in the field, concretely that the implementation of relocation of fishermen's houses in the coastal area of Mataram City based on Mataram City Regional Regulation Number 5 of 2019 has not been fully realized. The obstacles in the implementation of relocation of fishermen's houses in the coastal area of Mataram City are caused by juridical and non-juridical factors, the following authors will describe these factors..

a) Juridical factors

Public policies largely determine sustainable coastal life. Spatial planning is one form of management policy that includes spatial planning, utilization and supervision, is an inseparable series, must be carried out as a general policy as a form of law, in the form of regulation with all its implementation tools in the form of institutions and policy actors through good, transparent and regulatory mechanisms. consistent.

Based on the results of the author's research in the field, it was found that the implementation of the relocation of coastal communities should not run smoothly, there were several juridical factors in the implementation of relocation, namely in the form of :

1) Relocation area

Based on the results of the author's interview with Mr. Wahyu Hidayat as the Head of the Public Works, Settlement and Transportation Sub-Division of the NTB Province Bappeda said that; "We, the provincial government, have not fully acquired the land which will be used as a new settlement by the coastal community, so the implementation of relocation has not been maximally carried out.".

2) Lack of Human Resources

3) In the implementation of the relocation program, the local village formed Pokja Induk as a village-level working group. The task of Pokja Induk is one of which is to inventory or record citizens who are entitled to assistance in the relocation program. With the lack of human resources owned by each village, the stages in the implementation of coastal community relocation can not run smoothly.

4) Fiscal / Funds

The implementation of the relocation does not run due to the lack of budget provided by the local government, the local government does not yet have a budget for land acquisition relocation.

b) Non-juridical factors

The relocation in the coastal area in Ampenan District is a policy carried out by the Mataram City Government as a solution to existing coastal settlements that are often affected by natural disasters such as abrasion. The relocation program carried out in Ampenan District is carried out by moving residents to a residential location that has been provided by the government. Relocation is defined as moving or moving locations from one place to another for certain reasons.

Preparation of spatial planning based on disaster mitigation needs to prioritize natural disasters such as abrasions that have occurred or are about to occur. Many problems arise when preparing this plan, especially after a disaster due to changes in morphology, topography, and socio-economic conditions of the community. In accordance with Law Number 26 of 2007 concerning Spatial Planning, districts and cities are given the authority to compile comprehensive spatial plans by utilizing space and supervising and controlling activities in space.

In the implementation of the removal / relocation of coastal communities carried out by the government of the City of Mataram, there are not only obstacles caused by juridical factors as described above, but also nonjuridical factors. One of the non-juridical factors comes from the people of the coastal areas themselves, where they are reluctant / unwilling to be relocated by the government. The non-juridical factors are as follows :

1) Lack of socialization.

Lack of socialization carried out by the government to coastal residents, this is due to the fact that these regional regulations are still new and have not had time to be socialized. A similar thing was also expressed by one of the coastal residents who said that so far I have never received any socialization from the Mataram City 
government regarding the existence of Mataram City regional regulations regarding relocation.

2) Social Factors

The social factor in this case is the gap between expectations and reality. The point is that people in coastal areas really expect that at the time of relocation they will all receive large compensation from the government, but in reality only part of the community will receive compensation in accordance with whether or not there is evidence of the rights they have in the old place. If the community does not have proof of their rights, the City government will not provide compensation to them.

So far, based on the results of the author's research in the field, Regional regulation (Perda) No. 5 of 2019 concerning the Regional Spatial Plan for the City of Mataram 2011-2031, does not run consistently and coherently with the spirit of the Constitution and spatial planning law, due to the management of the legal structure (City Government). Mataram) which is ineffective. In fact, the relocation of fishermen's houses in coastal areas must be managed properly because it will have a negative impact on the environment and society.

If it is related to the theory of justice, then, of course, people in coastal areas do not get justice from the government, which is where the implementation of relocation of fishermen's houses should have been carried out by the city government. Hans Kelsen is of the view that law is a social order that can be declared fair if it can regulate human actions in a satisfying way so that we can find happiness in it.(Hans, 2011)

When referring to the opinion above which states that the law can be said to be fair if it can regulate human actions in a satisfying way so that they can find happiness, with the existence of Regional Regulation Number 5 of 2019, the coastal area community is unhappy with the relocation / restructuring because the community believes that the relocation site is very far from their current location.

The sense of justice that is reflected in a law book, may only be in tune with the sense of justice in society at the time the law was published. People in coastal areas feel that the existing condition does not or does not reflect a sense of justice anymore and this means that people hold back to the teachings of natural law. In addition to providing a sense of justice to coastal communities in the Ampenan District area, the City government in relocating coastal communities must see it from the point of view of legal benefit theory.

The usefulness of law can be seen by how to judge a public policy that has a moral impact on many people, whether a particular policy or action brings benefits or useful results or vice versa harm to the people concerned. The pros and cons of the law must be measured from the pros and cons of the results generated by the application of the law.

Based on the theory of legal benefits, the implementation of relocation of fishermen's houses in the coastal area of Mataram City has not fully shown any legal benefits. This can be seen based on the results of the author's research in the field, namely from the results of interviews with the Ampenan sub-district head, saying that some residents who would be relocated to a new place refused on the grounds that they would find it difficult to earn a living considering the place to be relocated was quite far from their current place. because most of the people's livelihoods are fishermen, if they are moved it will be difficult to find a new livelihood. The purpose of this Usability Theory is that an act of will aims to achieve as much happiness as possible.

In the implementation of the relocation of fishermen's houses in the coastal area of Mataram City, in addition to seeing the benefits should pay attention to the human rights of the people in the region. Human rights can be seen as an identity that distinguishes human beings from other beings, so it is appropriate that human rights are universally recognized regardless of skin color, gender, age, cultural background and religion or in other words non-discrimination.

The principle of non-discrimination is defined as a discriminatory or unequal situation if the same situation is treated differently and/or different situations are treated equally. This principle of non-discrimination is then very important in human rights. The understanding of discrimination then expands with the emergence of indicators of discrimination, namely freedom on race, color, gender, language, religion, political opinion, or other opinions, nationalists, ownership of an object, birth status and other status.

The implementation of relocation of fishermen's houses in coastal areas needs special attention from the Mataram City government, based on the theory of human rights where rights are something inherent in human beings that must be protected, respected, maintained and should not be ignored, reduced or seized by anyone. Therefore, in the implementation of the relocation of fishermen's houses in the coastal area of Mataram City if done regardless of ownership of an object, so that the community feels that the relocation carried out by the City government can provide benefits for the people of coastal areas and do not favor any party. This is a further consequence of the purpose of the state law, which is to protect and guarantee the human rights of its citizens from acts of arbitrariness.

Fulfillment of community rights impacted in the implementation of fisherman house relocation in coastal area of mataram city

Often the use of the terms "Beach" and "Coast" is not clearly and definitively defined. When reviewed in a juridical manner, it seems that both terms should be clearly understood. The re-use of both terms is intended to 
avoid doubt or uncertainty, both in the formulation of a regulation and in its implementation. Here's the definition of "Beach" and "Coastal". The beach is the meeting between the highest tide and the land. While the coastline is the water line that connects the meeting point between the highest tide and the land. The coastline will be formed following the land / land configuration itself. Coastal is the area where land and ocean influences meet. Direction of land covers certain areas, where the influence of the oceans is still felt (sea breeze, temperature, plants, seabirds, etc.). Whereas towards the coastal ocean, it can include marine areas where the effects of activities on land are still felt or are still visible (for example the appearance of pollutants, sedimentation, and water color). From this definition, it can be concluded that the definition of coast includes a broader area than the definition of coast.

In this context, it can also be distinguished between "Coastal Land" and "Coastal Land". Coastal land is the land that sits between the lowest low tide line and the highest tide, including the depth of the land from the highest tidal line to a certain distance inland, which is referred to as the "Coastal Border".

According to Presidential Regulation No.51 of 2016 concerning Coastal Boundaries, Coastal Borders are land along the shore, whose width is proportional to the shape and physical condition of the coast, at least 100 (one hundred) meters from the highest tide point towards the land. The coastal border area functions to prevent coastal abrasion and protect the coast from activities that can disturb / damage the function and sustainability of the coastal area. The coastal area is only allowed for plants that function as protection and beach protection, the use of public facilities that do not change the function of the land as protection and beach preservation.

1. Coastal boundaries

Coastal boundaries or coastal borders are coastal boundaries which are determined based on certain methods. So before determining the coastal demarcation line, first the shoreline is determined as a reference for drawing the boundaries of the boundary area. Coastline according to IHO Hydrographic Dictionary (1970) is the meeting line between the coast and water (ocean). although periodically, the sea level is always changing, a certain fixed and determinable sea level must be chosen to explain the position of the coastline.

In principle, the determination of the location of the coastal boundary line is calculated based on the characteristics of the coast, the function of the area, and is measured from the highest tide line on the beach concerned.(Sugito \& Sugandi, 2016)

2. Utilization of Coastal Borders

In the utilization of space in border areas or coastal areas the government issued Law No. 26 of 2007 on Spatial Planning, in the law has been outlined the provisions of the preparation of spatial alignment ranging from the content of the plan, aspects of implementation, aspects of detail, community participation and several points related to development arrangements.

In accordance with the mandate of Article 20 of Law Number 26 of 2007 concerning Spatial Planning, the National Spatial Planning (RTRWN) is a guideline for the preparation of national long-term development plans, preparation of long-term national development plans, spatial use and identification of spatial use in the national territory, realizing integration, and the balance of development between provinces, as well as harmony between sectors, and balance of development between provinces, as well as harmony between sectors, determination of locations and spatial functions for investment, arrangement of national strategic areas, and spatial planning of provincial and city / regency territories.(Hasni, 2008)

Spatial planning as a system of spatial planning, spatial use and control of space utilization is an inseparable unit from one another and is only carried out in accordance with spatial planning principles so that it is hoped that it can realize efficient and efficient spatial use and is able to support the management of the living environment. sustainable.(Hasni, 2008)

Regarding spatial planning, Mataram City issued Regional Regulation Number 5 of 2019 concerning Amendments to Regional Regulation Number 12 of 2011 concerning Regional Spatial Plans for the City of Mataram. Regarding the spatial relocation plan for the coastal area, it is contained in Article 11 paragraph 2 letter $g$ which states that they will relocate and / or rearrange fishing villages in areas prone to the threat of tidal waves / tsunami and coastal abrasion.

The relocation of fishing communities to coastal areas cannot be separated from the role of the Mataram city government which wants to protect coastal communities from the threat of tidal waves / tsunamis and coastal abrasion. In literal terms, according to the large Indonesian dictionary, relocation is defined as moving a place or moving from one location to another. If linked in this context, relocation settlements can mean the relocation of a settlement to a new settlement location.

Relocation is carried out for residential locations that are not designated for housing or settlement locations that are prone to disasters or even those affected by disasters. Relocation or resettlement is an alternative to provide opportunities for people living in coastal areas, whose land status is illegal or living in a disaster-prone environment to reorganize and continue their life in a new place..

The relocation or resettlement program is a program that is carried out with a very careful planning. The World Bank recommends that before deciding on a relocation plan it is necessary to prepare a thorough 
resettlement planning framework or policy framework. The relocation program was developed on a participatory basis, so that resettlement decisions were made by the community themselves.

In the implementation of relocation there are several things that must be considered, namely :

1. The need for coordination from the planning, implementation to evaluation stages

The problem of relocation is a complex problem because it involves three things, namely basic human needs for land and shelter, availability of land / area for relocation, and guarantees to continue their life. For displaced people, the opportunity to participate in the relocation program from an early stage and a strong belief that the program will run well and succeed as expected can be obtained if the community believes that the program is well coordinated, accompanied by access to information for the community.

2. Selection of Relocation Areas

The location and quality of the new relocation site is an important factor in relocation planning, as it greatly determines the ease of accessing to business land, social networks, jobs, business fields, credit and market opportunities. Each location has its own limitations and opportunities. Choosing a location that is similar to the former area (the old site) in terms of environmental, social, cultural and economic characteristics will make relocation and income recovery more successful.

Ideally, the new relocation site should be geographically close to the old / original place to maintain good social networks and community ties. In urban development projects, which often result in relocation in large numbers, these impacts can be reduced by relocating to various small and close areas. In such cases, the location selection and relocation plan must be based on, and decided upon by discussion with the community.

3. Rights of Community that will be transferred

To the community, information about prospective locations is conveyed and given the opportunity to review the sites that have been built before being officially submitted. This is necessary so that people can make their choices freely.

4. Physical completeness of resettlement site

If the choice has been made, the resettlement location must be completed with:

a. Decent road access;

b. Drainage channels;

c. Provision of clean water;

d. Electrical connection;

e. Public facilities, including educational facilities, businesses, places of worship, markets, sports fields, health facilities;

f. Ease of transportation.

5. Relevant shapes of houses and other buildings

Relocation problems are closely related to economic and socio-cultural problems, as well as problems of psychological recovery. Therefore, with regard to the form of houses and other buildings that are relevant, consultations with the community that will be moved are in accordance with the wishes of the residents.

6. Status of land rights

Land and buildings that have been handed over to the community are given legal certainty and protection in the form of property rights. Although officially the community has occupied the relocation area, monitoring and evaluation must still be carried out to find out if there are still deficiencies in its implementation so that the necessary improvements can be made..

7. Support for the restoration of people's life levels

Relocation is not only a process of moving people from a location, but when relocation occurs, the government must pay attention to the rights of the people affected by the relocation. Based on the results of the compilers' research in the field, from the results of interviews with the Head of Ampenan Sub-district, it was said that the rights of the coastal areas affected by the relocation were not fully fulfilled, this was because there were still many coastal communities who were reluctant to be relocated to a new place. People in coastal areas who want to be relocated will get compensation, which at the time of the compensation process the conditions that must be fulfilled by the community are one of them being able to show evidence of their rights to the land they previously occupied, in addition to compensation the Ampenan sub-district head also said that the coastal community Those affected by the relocation will be given a new place in the form of a house (flats) in Batu Layar.

Based on Regional Regulation Number 5 of 2019 concerning Amendments to Regional Regulation Number 12 of 2011 concerning RTRW for the City of Mataram, it does not mention the rights of fishing communities / coastal area communities to relocation, this regional regulation only mentions the regional plans for Mataram City in implementation of relocation in coastal areas.

The fulfillment of the rights of communities affected in the implementation of relocation of fishermen's houses in coastal areas needs special attention from the Mataram City government, based on the theory of human rights literally, human rights are rights inherent in humans, therefore they must be protected, respected, 
maintained and it must not be ignored, reduced or seized by anyone. So with that the fulfillment of the rights of fishing communities affected by relocation in the coastal area of Mataram City must be fulfilled immediately considering that human rights are rights that are owned by humans solely because they are human. Human beings have this right not because it is given by other parties, but solely because of their dignity as a human being.

The concept of human rights above, if traced more backward, emerged from the theory of natural rights. This theory emerged from natural law theory. Every right is determined objectively or subjectively. Objective means that the right is given to a person because it belongs to him. The subject means that the determination of rights is related to what they have. and be the master of what he has. The determination of this right is also closely related to legal and state affairs. Rights are determined objectively because that is their nature, as a manifestation of justice and are determined subjectively as a consequence of the stipulation of natural law. Recently, these subjectively determined rights are known as civil and citizen rights.

Talking about the rights of citizens, people in coastal areas are categorized as citizens' rights where the fulfillment of their rights is determined objectively, where the rights must be given because they belong to them. Based on the theory of natural rights, all communities living in coastal areas are gifted with inherent rights to life, freedom and ownership. Such is their own property and cannot be revoked or stripped down by the state. Protection of this inalienable right is handed over to the state through a social contract.

Fulfilling the rights of coastal communities must provide benefits to the community itself. Based on the theory of usability, it is necessary to think that in the formation of laws that law is aimed at the realization of justice and the interests of every individual without discriminatory exceptions. The purpose of fulfilling these rights is none other than how to provide the maximum benefit for the majority of society. For this school, the presence of law is to provide as many benefits to humans as possible.

In essence, law is expressed through its purpose, namely to provide protection for the interests of society and individuals through coordination between interests. Community interests must take precedence / priority if there is a conflict with individual interests. The theory of usability has the same goal of protecting interests by portraying them as the pursuit of pleasure and the avoidance of suffering. Usability theory emphasizes the importance of consequences of actions in judging good or bad. The moral quality of an action is said to be good or bad depending on the consequences or consequences it brings.

\section{Conclusion}

Based on the description that the author has described above, a conclusion can be drawn as follows:

1. The implementation of relocation of fishermen's houses in the coastal area of Mataram City is based on Regional Regulation Number 5 of 2019 concerning the Mataram City Spatial Plan 2011-2031, namely that the implementation of relocation is not fully realized due to the lack of socialization carried out by the government to coastal residents, this is due to the regulation The area is still new and has not had time to be socialized, besides that the relocation is not completely smooth due to the lack of budget provided by the local government, the local government does not have sufficient budget for relocation land acquisition.

2. Fulfillment of the rights of the affected communities in the implementation of relocation of fishing houses in the coastal area of Mataram City is carried out by providing compensation or compensation to people who have evidence of their rights to the land they previously occupied, apart from the right to compensation, the community is also entitled to all information related with the relocation stage.

\section{Suggestion}

From the above conclusions, several suggestions can be put forward which are expected to be material for thought in order to provide solutions to the problems faced, namely :

1. It is hoped that the city government of Mataram, after carrying out the relocation, will re-evaluate the location of the relocation of the flats which is the place of relocation, considering that there are so many problems that have arisen related to the implementation of the relocation. So it is hoped that this problem will not occur in the future.

2. It is hoped that there needs to be clear action from the government of Mataram City if there is a problem related to fulfilling the rights of the coastal area community, this must be done considering that not all people in coastal areas get their rights. Mataram City Government is expected to continuously disseminate information to the community regarding what rights they get from the relocation program.

\section{References}

Arba. (2017). Hukum Tata Ruang dan Tata Guna Tanah: Prinsip-Prinsip Hukum Perencanaan Penataan Ruang dan Penatagunaan Tanah. Cetakan I, Sinar Grafika, Jakarta.

Arief, B. N. (2000). Bunga rampai kebijakan hukum pidana.

Cornelis, V. I. (2016). Hukum Pemerintahan Daerah Pengaturan dan Pembentukan Daerah Otonomi Baru DI 
Wilayah Perbatasan dan Pendalaman dalam Perspektif Kedaulatan Bangsa (Vol. 1). Aswaja Pressindo (Members of LaksBang Group.

Dapu, Y. M. (2016). Implikasi UU N0. 23 Tahun 2014 Terhadap Kewenangan Urusan Pemerintahan Daerah di Bidang Kelautan dan Perikanan. Lex Et Societatis, 4(8).

Daud Silalahi, M. (2001). Hukum Lingkungan Dalam Sistem Penegakan Hukum Lingkungan di Indonesia. Alumni, Bandung.

Hans, K. (2011). General Theory of Law and State, diterjemahkan oleh Rasisul Muttaqien. Nusa Media, Bandung.

Hasni, M. (2008). Hukum Penataan Ruang dan Penatagunaan Tanah. Jakarta: Rajawali Pers.

John, R. (2006). Teori Keadilan. Cetakan Pertama, Pustaka Pelajar, Jogjakarta.

Kantaatmadja, M. K. (1994). Hukum Angkasa dan Hukum Tata Ruang. Mandar Maju Bandung. Hal, 115.

Kuswartojo, P. T. (1999). Lingkungan Binaan Untuk Rakyat. AKATIGA, Bandung.

Limbong, B. (2017). Pengadaan Tanah Untuk Pembangunan. Margaretha Pustaka, Jakarta.

Mokodongan, R. P., Rondonuwu, D. M., \& Moniaga, I. L. (2019). EVALUASI RENCANA TATA RUANG WILAYAH KOTAMOBAGU TAHUN 2014-2034. SPASIAL, 6(1), 68-77.

Options, N. L. (1997). Departemen Pendidikan dan Kebudayaan, Kamus Besar Bahasa Indonesia. Jakarta: Balai Pustaka.

Rasjidi, H. L. (2012). Pengantar Filsafat Hukum.

Ridlo, M. A. (2001). Kemiskinan di Perkotaan. Semarang: Penerbit Unissula.

Ridwan, J., Sodik, A., \& Alwustho, M. (2008). Hukum tata ruang dalam konsep kebijakan otonomi daerah: lampiran: undang-undang nomor 26 tahun 2007 tentang penataan ruang. Nuansa.

Ridwansyah, M. (2016). Mewujudkan Keadilan, Kepastian dan Kemanfaatan Hukum dalam Qanun Bendera dan Lambang Aceh. Jurnal Konstitusi, 13(2), 278-298.

Rijadi, P. (2005). Pembangunan hukum penataan ruang dalam konteks kota berkelanjutan. Airlangga University Press.

Said, S. (2011). dkk, Buku Ajar Pengantar Ilmu Hukum, cetakan II. Total Media, Yogyakarta.

Simarmata, J. (2018). PERSPEKTIF KEBIJAKAN DAERAH DALAM KONTEKS UU NO. 23 TAHUN 2014 TENTANG PEMERINTAHAN DAERAH DAN PERATURAN PERUNDANG-UNDANGAN TERKAIT (THE PERSPECTIVE OF LOCAL POLICY IN CONTEX OF LAW NUMBER 23 OF 2014 ON LOCAL GOVERNMENT AND OTHER RELATED LAWS). Jurnal Legislasi Indonesia, 12(2).

Sirajuddin, \& Winardi. (2017). Dasar-Dasar Hukum Tata Negera Indonesia. Cetakan I, Setara Press, Malang.

Soekanto, S. (2007). Faktor-faktor yang mempengaruhi penegakan hukum. PT.Raja GrafindoPersada, Jakarta.

Sugito, N. T., \& Sugandi, D. (2016). Urgensi Penentuan Dan Penegakan Hukum Kawasan Sempadan Pantai. Jurnal Geografi Gea, 8(2).

Tugault, Y. (1965). Abrams Charles-Man's Struggle for Shelter in an Urbanizing World. Population, 20(4), 715.

Wahid, A. M. Y., \& SH, M. S. (2016). Pengantar Hukum Tata Ruang. Prenada Media.

Wibowo, G. D. H. (2014). Dinamika Hukum Lingkungan dan Tata Ruang. Cetakan I, Pustaka Bangsa, Mataram.

Yudohusodo, S. (1991). Rumah untuk seluruh rakyat. INKOPPOL, Unit Percetakan Bharakerta. 